NOTE

\title{
Prevalence of infectious salmon anaemia virus (ISAV) in wild salmonids in western Norway
}

\author{
H. Plarre ${ }^{1}$, M. Devold ${ }^{1}$, M. Snow ${ }^{2}$, A. Nylund ${ }^{1, *}$ \\ ${ }^{1}$ Department of Biology, University of Bergen, PO Box, 5020 Bergen, Norway \\ ${ }^{2}$ FRS Marine Laboratory, PO Box 101, Victoria Road, Torry, Aberdeen AB11 9DB, UK
}

\begin{abstract}
Studies of infectious salmon anaemia virus (ISAV), an important pathogen of farmed salmon in Norway, Scotland, the Faeroe Islands, Ireland, Canada, the USA and Chile, suggest that natural reservoirs for this virus can be found on both sides of the North Atlantic. Based on existing information about ISAV it is believed to be maintained in wild populations of trout and salmon in Europe. It has further been suggested that ISAV is transmitted between wild hosts, mainly during their freshwater spawning phase in rivers, and that wild salmonids, mainly trout, are possible carriers of benign wild-type variants of ISAV. Change in virulence is probably a result of deletions of amino acid segments from the highly polymorphic region (HPR) of benign wild-type isolates after transmission to farmed salmon. Hence, it has been suggested that the frequency of new outbreaks of ISA in farmed salmon could partly reflect natural variation in the prevalence of ISAV in wild populations of salmonids. The aims of the present study were to screen for ISAV in wild salmonids during spawning in rivers and to determine the pathogenicity of resultant isolates from wild fish. Tissues from wild salmonids were screened by RT-PCR and real-time PCR. The prevalence of ISAV in wild trout Salmo trutta varied from 62 to $100 \%$ between tested rivers in 2001. The prevalence dropped in 2002 , ranging from 13 to $36 \%$ in the same rivers and to only $6 \%$ in 2003. All ISAV were nonpathogenic when injected into disease-free Atlantic salmon, but were capable of propagation, as indicated by subsequent viral recovery. However, non-pathogenic ISAV has also been found in farmed salmon, where a prevalence as high as $60 \%$ has been registered, but with no mortalities occurring. Based on the results of the present and other studies, it must be concluded that vital information about the importance of wild and man-made reservoirs for the emergence of ISA in salmon farming is still lacking. This information can only be gained by further screening of possible reservoirs, combined with the development of a molecular tool for typing virulence and the geographical origin of the virus isolates.
\end{abstract}

KEY WORDS: ISA virus · Wild salmonids · Natural reservoir Resale or republication not permitted without written consent of the publisher

\section{INTRODUCTION}

Infectious salmon anaemia virus (ISAV) is the etiological agent of a disease that has occurred in most salmon Salmo salar-producing countries worldwide (Thorud \& Djupvik 1988, Mullins et al. 1998, Rodger et al. 1998, Rowley et al. 1999, Bouchard et al. 2001, Kibenge et al. 2001, Ritchie et al. 2001). The official history of ISA dates back to 1984 in Norway, but the virus must be much older, being a distant relative of other viruses in the family Orthomyxoviridae (Krossøy et al. 1999). Based on the mutation rate of the RNAdependent RNA polymerase (ISAV Segment 2) and hemagglutinin genes (Segment 6), North American and European isolates are thought to have separated $>100$ yr ago (Krossøy et al. 2001, Krossøy 2002, Nylund et al. 2003). The demonstrated existence of ISAV on both the European and North American continents 
prior to the advent of intensive salmon aquaculture, suggests the long-term maintenance of ISAV in a wild reservoir. ISAV and raised levels of ISAV-specific antibodies have been found in wild salmonids with no clear relationship to aquaculture activity (Raynard et al. 2001a, K. Falk pers. comm.). Furthermore, studies based on sequencing of a so-called highly polymorphic region (HPR) of the haemagglutinin gene have suggested that all pathogenic ISAV isolates may be derived by differential deletions or by recombination of a potential ancestral sequence obtained from wild fish (Devold et al. 2001, Cunningham et al. 2002, Mjaaland et al. 2002, Nylund et al. 2003). Coupled to the fact that a range of salmonids have been experimentally shown to propagate ISA (Nylund et al. 1994a, 1995a,c, 1997, Nylund \& Jakobsen 1995, Rolland \& Nylund 1998a, Devold et al. 2000, Snow et al. 2001a,b, Rolland \& Winton 2003), this evidence suggests that wild salmonids may constitute natural host species within which an avirulent ISAV subtype may have co-evolved.

The most frequent interactions between individual wild salmonids and, hence, opportunities for ISAV transmission between hosts occur during spawning in rivers. The rivers are also the rearing areas for susceptible fry, parr and smolts, i.e. individuals that can be expected to lack the acquired immunity towards viral diseases. Based on these facts it is expected that a virus, which has co-evolved with salmon/trout, should be adapted to transmission in the freshwater phase, i.e. in the rivers and preferably during spawning when the chances of interactions between individuals are highest. It has been documented that the production of ISAV in trout increases during stress and sexual maturation (Nylund et al.1994a, 1995a, Rolland \& Nylund 1998a, Devold et al. 2000). It has also been thoroughly documented that the ISAV can be transmitted in both freshand seawater, and it has been shown that the virus can be present in the mucus, urine, faeces and ovarian fluids of infected individuals (Thorud \& Djupvik 1988, Thorud 1991, Nylund et al. 1993, 1994a,b, 1995a,b, 1997, 1999, Hovland et al. 1994, Nylund \& Jakobsen 1995, Totland et al. 1996, Rolland \& Nylund 1998a,b, Jones et al. 1999, Melville \& Griffiths 1999, Devold et al. 2000, Jones \& Groman 2001, Raynard et al. 2001b, Snow et al. 2001a,b).

Wild trout and salmon from 5 different rivers were collected and screened for the presence of ISAV. Two different areas in western Norway with frequent outbreaks of ISA in farmed salmon were selected, and fish were collected during spawning in the rivers in late October of 2001, 2002 and 2003. Pathogenicity characteristics of resultant ISAV were tested by intraperitoneal injection into disease-free salmon.

\section{MATERIALS AND METHODS}

Sample collection. Wild salmonids, trout Salmo trutta and salmon Salmo salar, from 5 selected rivers (Austgulen, Nordgulen, Takle, Brekke and Bortne) in western Norway were collected on 23 October 2001, on 29/30 October 2002 and on 28/29 October 2003 (Fig. 1). All 5 rivers are located in Sogn- og Fjordane county, in areas that traditionally have had a high density of salmon farms. Bortne River is located in the outer part of Nordfjord, while the other 4 rivers are located in the outer part of Sognefjord. Both areas have experienced frequent outbreaks of ISA since the early 1990s. Fish from these rivers were obtained by electrofishing from the river mouth and a maximum of $1 \mathrm{~km}$ up the rivers (Table 1). In the spring of 1998 , 45 sea trout $S$. trutta were collected by trawl from the outer part of Nordfjord, i.e. the same fjord where the Bortne River is located.

Tissue samples from gills, heart, liver, kidney, pseudobranch, gut, spleen and gonads were taken from the newly killed fish and immediately frozen in

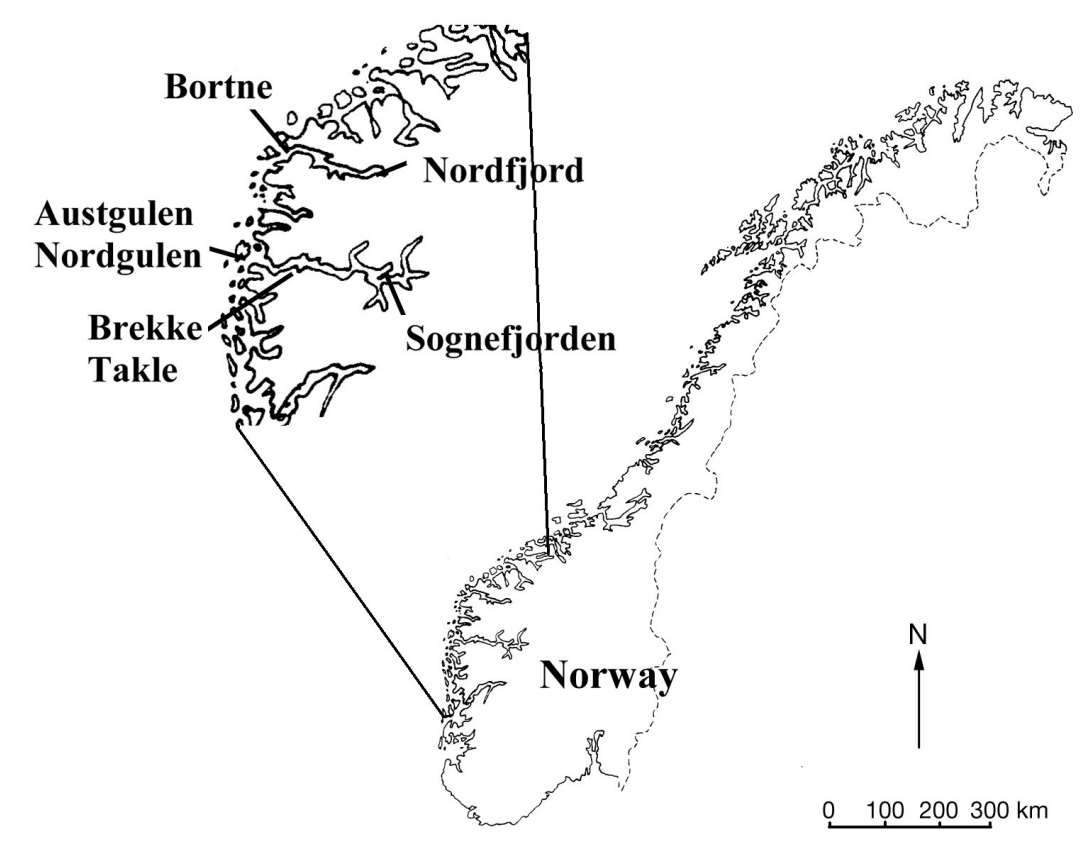

Fig. 1. Location of the rivers in western Norway where the trout and salmon were collected in 2001, 2002 and 2003 
Table 1. Salmo trutta, S. salar, Oncorhynchus mykiss. Material collected from 5 rivers in 2001, 2002 and 2003 and 1 fjord in 1998 (L-range: size range [cm] of the collected fish)

\begin{tabular}{|llcccccc|}
\hline & Species & N & Male & Female & Not mature & L-range & Year \\
\hline Rivers & & & & & & & \\
Nordgulen & S. trutta & 21 & 10 & 10 & 1 & $18.5-47.0$ & 2001 \\
& S. trutta & 24 & 14 & 6 & 4 & $18.5-50.0$ & 2002 \\
& S. trutta & 25 & 15 & 10 & 11 & $10.0-41.5$ & 2003 \\
Brekke & S. trutta & 12 & 5 & 5 & 2 & $17.5-47.5$ & 2001 \\
& S. salar & 4 & - & 4 & - & $50.0-60.0$ & 2002 \\
& S. trutta & 26 & 8 & 8 & 10 & $19.0-50.0$ & 2002 \\
Austgulen & S. trutta & 27 & 20 & 7 & 7 & $13.5-65.0$ & 2003 \\
& S. trutta & 13 & 3 & 4 & 6 & $17.5-35.0$ & 2001 \\
Takle & O. $m y k i s S$ & 1 & 1 & & & 22.5 & 2001 \\
Bortne & S. trutta & 4 & 2 & 2 & - & $16.5-21.0$ & 2001 \\
& S. salar & 3 & 3 & - & - & $60.0-80.0$ & 2002 \\
& S. trutta & 24 & 10 & 4 & 10 & $20.0-60.0$ & 2002 \\
& S. salar & 1 & - & 1 & 1 & 10.5 & 2003 \\
Fjord & S. trutta & 16 & 10 & 6 & 7 & $10.5-31.0$ & 2003 \\
Nordfjord & S. trutta & 45 & - & - & 45 & - & 1998 \\
& & & & & & & \\
\hline
\end{tabular}

scription, $12.5 \mu$ TaqMan Universal Master Mix $(2 \times), 900 \mathrm{nM}$ of each primer and $200 \mathrm{nM}$ of the MGB probe. The total volume was adjusted to $25 \mu \mathrm{l}$ using RNAse-free water. The reaction cycle was $2 \mathrm{~min}$ at $50^{\circ} \mathrm{C}$ (UNG activation), $10 \mathrm{~min}$ at $95^{\circ} \mathrm{C}$ and 45 cycles of $95^{\circ} \mathrm{C}$ for $15 \mathrm{~s}$, and $1 \mathrm{~min}$ at $60^{\circ} \mathrm{C}$. Two different real-time assays were designed for detecting the ISAV genome: 1 assay for Segment 7 (the tentative nonstructural protein genes) and 1 assay for Segment 8 (the tentative matrix protein genes) (Table 2). An $84 \mathrm{bp}$ and a $63 \mathrm{bp}$ region were amplified from Segments 7 and 8, respectively. The labelled fluorogenic probes are specific for the cDNA region between the forward and reverse primer sets. The probes contain a fluorescent reporter dye and a quencher dye; their physical proximity to each other suppresses any light emitted by the reporter. During PCR, the $5^{\prime} \rightarrow 3^{\prime}$

liquid nitrogen. On arrival at the laboratory, the tissues were transferred to $-80^{\circ} \mathrm{C}$.

Virus isolation and detection. Culture of ISAV was attempted by inoculation of positive tissues on Atlantic salmon kidney (ASK) cells (Devold et al. 2000) using 3 passages. Positive cell cultures, i.e. cell cultures showing a cytopathic effect (CPE), and negative cell cultures were all tested for possible presence of ISAV by RT-PCR (primers: FA-3/RA-3) (Devold et al. 2000).

ISAV-positive homogenates of tissues from salmon in each river (with the exception of the Takle River) were injected intraperitoneally into 30 disease-free salmon, to see if any mortality would occur and if the virus could be cultured in salmon. The tissue samples from wild and experimentally challenged fish were screened by RT-PCR using the diagnostic primers FA-3/RA-3 (Devold et al. 2000) and by real-time PCR. Extraction of RNA from the tissues, reverse transcription polymerase chain reaction (RT-PCR) and sequencing of PCR products were performed as described by Devold et al. (2000). The results of the RT-PCR and real-time PCR assays on the wild fish were tested by contingency table analysis to see if prevalence was significantly different in the 3 following years.

The reaction mix for the real-time PCR was as follows: $1 \mu \mathrm{l}$ of singlestranded cDNA from the reverse tran-
Table 2. Primer and probes in the assay mix were produced by Applied Biosystems (ABI). The probes are specific for the region between the primer sets and are targeted against Segments 7 and 8 from the ISAV (infectious salmon anaemia virus) genome

\begin{tabular}{|lll|}
\hline Primers/probes & Name & Sequence \\
\hline Segment 7 & & \\
Probe & S7-P1 & 6FAM-cac atg acc cct cgt c-MGBNFQ \\
Forward primer & S7-F1 & 5'-tgg gat cat gtg tt cct gct a \\
Reverse primer & S7-R1 & 5'-gaa aat cca tgt tct cag atg caa \\
Segment 8 & & \\
Probe & S8-P1 & 6FAM-acg gtg gat ctt tc-MGBNFQ \\
Forward primer & S8-F1 & 5'-cga cga tga ctc tct act gtg tga t \\
Reverse primer & S8-R1 & 5'-tca tca gtg tcg cca tgc tt \\
\hline
\end{tabular}


Sequencing and sequence analysis. PCR products were purified using Qia-quick PCR purification columns (Qiagen) and then sequenced using the Big Dye terminator Sequencing kit (Applied Biosystems). The templates were sequenced in both directions. Sequence data were assembled with the help of Vector NTI software (InforMax), and GenBank searches were performed using BLAST (2.0).

The Vector NTI Suite software package (InforMax) was used for the multiple alignments of partial nucleotides. To perform pairwise comparisons between the different sequences from the ISAV isolates, the multiple sequence alignment editor GeneDoc was used. Phylogenetic analyses of the data sets were performed using PAUP* Version 4.0 (Swofford 1998) and TREE-PUZZLE 5.0 (available at: www.tree-puzzle.de). TREE-PUZZLE reconstructs phylogenetic trees from molecular data by maximum likelihood, and computes maximum-likelihood distances and branch lengths. Phylogenetic trees were drawn using TreeView (Page 1996).

\section{RESULTS}

Trout Salmo trutta were the dominating salmonid species in the rivers and fjords where the fish were collected and screened for the presence of ISAV. The sample material also included a few Atlantic salmon Salmo salar from 2 rivers (Bortne \& Brekke) and 1 individual of rainbow trout Oncorhynchus mykiss collected in the Austgulen River. The majority of fish from the rivers were spawning or had just spawned, but a few parr and smolt were also included in the collected material. Except for the rainbow trout, none of the fish seemed to be escapees from fish farms. The weight of the fish was not measured, but their length, the number of fish caught, their sex and the number of immature fish are given in Table 1. The mean length of the fish caught in 2003 was much smaller and more fish were immature compared to those caught during the previous years.

None of the fish showed any clinical signs of ISA. However, 1 spawning salmon from the Bortne River (2002) had skin ulcers, and 1 immature trout from the Brekke River (2003) had white granulomas and an enlarged kidney. In 20035 trout (4 immature, 1 spawning) had nodules/vesicles on their spleens, while 1 spawning trout from the Brekke River was infected with Anisakis simplex, and 1 spawning trout from the Bortne River was heavily infected with Eubothrium sp. All the fish were screened for the presence of ectoparasites. A few of the fish had salmon lice, Lepeophtheirus salmonis, Trichodina spp. and Riboscyphidia sp., but the intensity was low, and no lesions due to parasites were observed.

\section{Virus detection}

It was not possible to culture any ISAV in ASK cells from any of the fish included in this study. However, it was possible to detect ISAV in salmon, challenged with tissue homogenates from ISAV-positive fish, $4 \mathrm{wk}$ after challenge, but no mortality was observed. Sequencing of the PCR products and phylogenetic analysis of the sequences, confirmed them to be ISAV genomes of European origin.

The kidneys from all the collected fish were screened for the presence of ISAV with the help of RTPCR (primers: FA-3/RA-3), and fish collected in 2002 and 2003 were also screened by real-time PCR using primers and probes targeting Segment 8. Both the Segment- 7 and -8 real-time PCR assays were used in the screening of the material from 2003. The real-time PCR assays were more analytically sensitive than the RTPCR (FA3/RA3), and gave positive reactions with 1000 times less template than the RT-PCR (Fig. 2). The results of the RT-PCR and real-time tests are presented in Table 3, and this table shows a clear trend: the highest prevalence of ISAV was detected in 2001 (up to $100 \%$ ), it decreased during 2002 to a maximum of $81 \%$ and reached a low point in 2003, with no more than 1 fish testing positive for ISAV in each river. This trend can be observed in all rivers and is confirmed by both RT-PCR and real-time PCR. The results of the RT-PCR and real-time PCR assays on the wild fish were tested by contingency table analysis (Table 3). Only 3 of the 45 sea trout collected in 1998 were positive for ISAV.

Unfortunately, only 3 fish were available for testing the tissue distribution of virus in ISAV-positive fish in 2003, 2 that were immature and 1 that was spawning. The results are presented in Table 4 and show that ISAV was only detected in 4 of the 8 tissues tested.

\section{DISCUSSION}

Molecular methods have become important tools in viral diagnostics and in the study of the diversity, maintenance and dissemination of viral diseases (Hungnes et al. 2000). The latest revolution in viral diagnostics came with the development of real-time PCR due to its rapidity, sensitivity (i.e. low detection limit), reproducibility and the reduced risk of carry-over contamination (Mackay et al. 2002). In addition, it provides the possibility for relative and absolute quantification. The high sensitivity of real-time PCR makes it a good method for detection of carriers of viral agents like the ISAV, since it must be expected that orthomyxoviruses have to produce a low number of infective particles in order to persist in the host (Knipe \& Howley 2001). PCR has established itself during recent years as the gold 

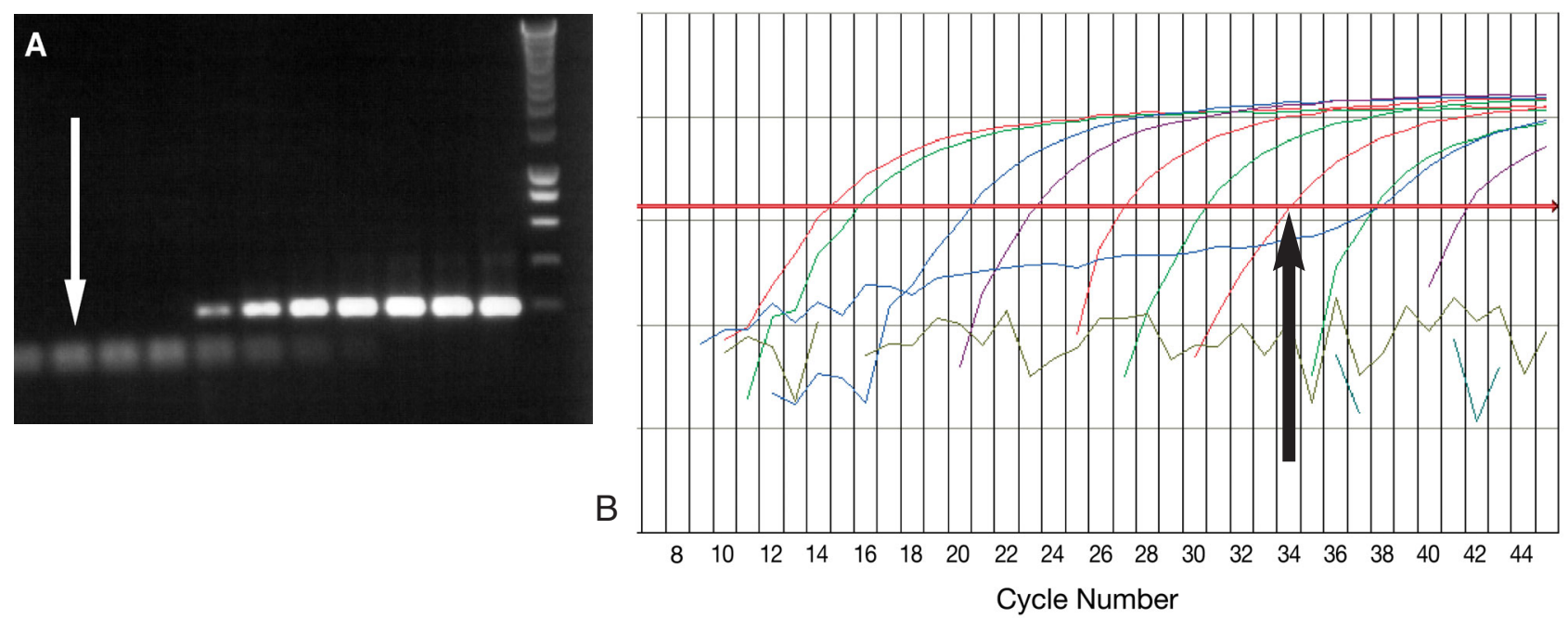

Fig. 2. (A) Demonstrating the difference in threshold of detection of infectious salmon anaemia virus by RT-PCR (FA3/RA3) and the 2 real-time PCR assays targeting Segments 7 and 8. Agarose gel showing RT-PCR amplification products (10 $\mu$ l) stained by ethidium bromide. The lanes represent 10 -fold dilutions. The white arrow marks the dilution that could be detected by the real-time PCR assays. (B) Results of the real-time PCR assay targeting Segment 7 using the same dilution series as in the RT-PCR. The black arrow shows the detection limit for the RT-PCR

standard for detecting nucleic acids from a number of origins, and RT-PCR has become an important tool in the diagnostics of ISA in both Europe and North America (Mjaaland et al. 1997, Devold et al. 2000, Griffiths \& Melville 2000, Mikalsen et al. 2001, Raynard et al.

Table 3. Salmo trutta, S. salar, Oncorhynchus mykiss. Results of the RT-PCR and real-time PCR screening of kidney tissues from wild trout $S$. trutta and salmon $S$. salar caught in rivers located in western Norway (nt: not tested; n: number of positive fish; \%: percentage of positive fish). Results of the RT-PCR and real-time PCR assays on the samples of $S$. trutta collected in 2001, 2002 and 2003 from the Nordgulen, Brekke and Bortne Rivers were tested by contingency table analysis $\left(\chi^{2} / \mathrm{p}<\right)$. There was a significant decline of ISAV-positive trout in all 3 rivers using both assays for detection

\begin{tabular}{|c|c|c|c|c|c|c|c|}
\hline & Species & $\mathrm{N}$ & $\begin{array}{c}\text { RT-PCR } \\
\text { n/\% }\end{array}$ & $\chi^{2} / \mathrm{p}<$ & $\begin{array}{l}\text { Real-time } \\
\text { PCR n/\% }\end{array}$ & $\chi^{2} / \mathrm{p}<$ & Year \\
\hline \multicolumn{8}{|l|}{ Rivers } \\
\hline \multirow[t]{3}{*}{ Nordgulen } & S. trutta & 21 & $14 / 67$ & \multirow{3}{*}{$30.3 / 0.001$} & $\mathrm{nt}$ & & 2001 \\
\hline & S. trutta & 24 & $3 / 13$ & & $9 / 38$ & & 2002 \\
\hline & S. trutta & 25 & $0 / 0$ & & $1 /(4)$ & 8.5/0.01 & 2003 \\
\hline \multirow[t]{4}{*}{ Brekke } & S. trutta & 12 & $8 / 67$ & \multirow{4}{*}{$21.1 / 0.001$} & nt & & 2001 \\
\hline & S. salar & 4 & $3 / 75$ & & $4 /(100)$ & & 2002 \\
\hline & S. trutta & 26 & $7 / 27$ & & 21/81 & $32.4 / 0.001$ & 2002 \\
\hline & S. trutta & 27 & $0 / 0$ & & $1 /(4)$ & & 2003 \\
\hline \multirow[t]{2}{*}{ Austgulen } & S. trutta & 13 & $13 / 100$ & \multirow{7}{*}{$6.6 / 0.01$} & nt & & 2001 \\
\hline & O. mykiss & 1 & $1 / 100$ & & $\mathrm{nt}$ & & 2001 \\
\hline Takle & S. trutta & 4 & $3 / 75$ & & $\mathrm{nt}$ & & 2001 \\
\hline \multirow[t]{4}{*}{ Bortne } & S. salar & 3 & $0 / 0$ & & $2 /(67)$ & & 2002 \\
\hline & S. trutta & 24 & $8 / 34$ & & $15 / 63$ & & 2002 \\
\hline & S. trutta & 16 & $0 / 0$ & & $1 /(6)$ & $12.7 / 0.001$ & 2003 \\
\hline & S. salar & 1 & $0 / 0$ & & $0 /(0)$ & & 2003 \\
\hline \multicolumn{8}{|l|}{ Fjord } \\
\hline Nordfjord & S. trutta & 45 & $3 / 6.7$ & & nt & & 1998 \\
\hline
\end{tabular}

2001a,b, Snow et al. 2001a, 2003, Løvdal \& Enger 2002, McClure et al. 2004). The dominating assays for RTPCR detection of ISAV have been an assay published by Mjaaland et al. (1997) and another assay developed by Devold et al. (2000). Both assays target Segment 8, presumably the matrix protein genes from the ISAV (Biering et al. 2002). The real-time PCR used in the present paper is able to detect template 1000 times more dilute than the RT-PCR assay (FA3/RA3) developed by Devold et al. (2000). This difference in sensitivity is also reflected by the results presented in this study, in which the real-time PCR in each case gives a higher number of ISAV-positive individuals.

The official history of the ISAV in salmon farming goes back to 1984 in western Norway (Thorud \& Djupvik 1988). However, based on the mutation rate of the RNA-dependent RNA polymerase gene, Krossøy et al. (2001) estimated that the European and North American isolates of ISAV must have separated at least $100 \mathrm{yr}$ ago. More than $100 \mathrm{yr}$ of separation between European and North American ISAV isolates was also supported by a study of the mutation rate of the haemagglutinin gene (Segment 6) of the ISAV (Nylund et al. 2003). A dis- 
Table 4. Salmo trutta, S. salar, Oncorhynchus mykiss. Tissue distribution of ISAV in positive carrier fish from 3 rivers (Bortne, Brekke, Nordgulen) using real-time PCR. The first PCR was done on kidney tissue only to check for absence/presence of ISAV; the second PCR was done on various tissues from ISAV-positive fish in order to determine tissue distribution of virus. Superscript 7 and 8 ; PCR for Segment 7 and 8, respectively. nt: not tested; Ct: cycle thresholds of the growth curves

\begin{tabular}{|clccc|}
\hline & \multirow{2}{*}{ Tissue } & \multicolumn{3}{c|}{ Ct } \\
\cline { 3 - 5 } & & Bortne & Brekke & Nordgulen \\
\hline 1st PCR & Kidney & $36.96^{7}$ & $38.12^{7}$ & $39.29^{8}$ \\
2nd PCR & Kidney & $30.88^{7} / 29.16^{8}$ & - & - \\
& Pseudobranch & - & - & - \\
& Gill & - & - & - \\
& Heart & - & $36.95^{8}$ & $38.08^{8}$ \\
Liver & - & - & - \\
Spleen & $32.51^{7}$ & - & - \\
Gonads & nt & nt & - \\
Gut & $40.22^{8}$ & - & - \\
\hline
\end{tabular}

tant relationship to the other members in the family Orthomyxoviridae, the influenza viruses (Krossøy et al. 1999), suggests a very old and probably a marine origin for the ISAV. This has led to a hunt for the marine reservoirs of ISAV, and many marine fish species have been challenged to see if they could be hosts for the ISAV (Thorud \& Torgersen 1994, Kvenseth 1998, Nylund et al. 2002, Snow et al. 2002). So far, only limited replication has been found in herring Clupea harengus (Nylund et al. 2002). On the other hand, the ISAV is able to replicate in most salmonid species, Salmo spp., Oncorhynchus spp. and Salvelinus alpinus (Nylund et al. 1994a, 1995a,b, 1997, Nylund \& Jakobsen 1995, Rolland \& Nylund 1998a, Devold et al. 2000, Snow et al. 2001a,b, Rolland \& Winton 2003), causing mortality in Atlantic salmon only (Thorud \& Djupvik 1988, Mullins et al. 1998, Rodger et al. 1998, Bouchard et al. 2001). Based on empirical and experimental evidence, everything points towards salmonids as the natural hosts of ISAV, and, in Norway, this means in most cases Atlantic salmon $S$. salar and trout $S$. trutta.

All salmonids have a freshwater phase when they are young, and this early phase is, for most salmonid species, followed by a marine phase (growth phase). At the start of sexual maturation the salmonids at sea return to freshwater, usually rivers, to spawn. Hence, the highest population densities of hosts will be found in rivers during spawning, where, in addition to mature salmonids, there will be an abundance of younger, susceptible stages of the same species (cf. Nylund et al. 2003). In a natural system, the most obvious place to look for the ISAV would, therefore, be in salmonid hosts during spawning. The present study, based on the material collected in 2001 and 2002, strongly supports such a view. Both RT-PCR and realtime PCR resulted in a high number of positive individuals of trout in both years, but higher in 2001 compared to 2002. However, the number of positive individuals dropped significantly in 2003 when only 1 individual fish was found positive in each of the 3 rivers that were screened. In 1998 a similar screening for ISAV was performed (RT-PCR using FA3/RA3) on sea trout $(\mathrm{N}=45)$ collected in Nordfjord (the fjord where the Bortne River empties) and 3 individuals, $6.7 \%$, were found to be positive. Salmonids in freshwater in the UK have also been found positive for ISAV, and it was suggested that they were infected by transmission of virus from ISAV-positive marine farming sites (Raynard et al. 2001a). Hence, important questions are: What connections exist between wild and farmed salmonids? Can changes in infection pressure from ISAV-positive salmon farms explain the large drop in number of ISAV-positive wild fish from 2001 to 2003? Does the pattern of ISAV prevalence in wild fish reflect the infection pressure from marine salmon farms or vice versa, or is the observed pattern just reflecting natural variation within these populations?

Most marine salmon farms close to these rivers were empty in the period summer 2002 to summer 2003 due to earlier problems with ISA. They have now been restocked. On the other hand, it is also known that the prevalence of virus in natural populations may vary from year to year depending on the status of acquired immunity within the respective populations (Knipe \& Howley 2001). Testing of the ISAV from the wild fish showed that none of these gave any pathology or mortality when injected into disease-free salmon, but they did replicate, i.e. the ISAV were still detected 4 wk after the challenge. Avirulent ISAV have also been detected in farmed salmon in western Norway (A. Nylund unpubl. data), and, hence, farmed salmon could have been responsible for the high prevalence of ISAV in the rivers in 2001 and 2002. However, this would not be the pathogenic ISAV isolates collected from farms in these 2 areas in the period from 2000 to 2003. To better understand the relationship between the prevalence of ISAV in wild salmonids and the occurrence of ISA in farmed salmon, it will be necessary to screen wild populations of salmonids over a longer period (maybe $10 \mathrm{yr}$ ). The results from such a study should be correlated with data on ISA from salmon farms in the same areas. In addition, if possible, a molecular typing system for geographical origin and virulence should be developed to aid the interpretation of the results from such a study.

It is obviously too early to have any firm opinions about what is happening in the western Norwegian river systems included in this study. However, the 
occurrence of ISAV in Norway, Canada, the UK, the Faeroe Islands, the USA and Ireland represent separate events, including different ISAV isolates (Nylund et al. 2003). In all these cases, the emergence of ISAV must have local natural reservoirs (nothing is known about the Irish ISAV). This assumption is further supported by the discovery of ISAV, in Scotland and Canada, with full-length HPRs in the HA gene (Segment 6), i.e. sequences not previously observed in any other countries (Cunningham et al. 2002, CookVersloot et al. 2004). Full-length HPRs were later also found in ISAV from farmed salmonids in the USA and Norway (A. Nylund unpubl. data), and these viruses are different from each other and from those described in the UK and Canada. A study of ISAV isolates from Norway, based on sequences of the HA gene, shows that there are several distinct groups of ISAV in Norway (Devold et al. 2001, Nylund et al. 2003). These isolates reflect geographical origin and time of collection, and, based on this information, Nylund et al. (2003) suggest that at least 21 transmissions from wild to farmed salmonids are represented in the material presented. Still, it is a long way from the estimated number of transitions from wild to farmed fish that can be documented to the hundreds of outbreaks of ISA in salmon farming through the years. A number of these outbreaks can be explained as horizontal transmissions between salmon farms and spreading of ISAV via transportation of infected smolts, but the tools needed to quantify this type of transmission are not available. Hence, there are large numbers of ISA cases in salmon farming for which transmission from wild fish or between salmon farms cannot be determined. Future management of ISA does, however, require knowledge about the source of the ISAV responsible for new outbreaks. We, therefore, recommend that more resources should be put into the study of natural reservoirs, man-made reservoirs (farmed stocks of salmonids) and the development of better molecular tools for typing of ISAV isolates with respect to geographical origin and virulence.

The work on tissue distribution, presented in this study, is limited to 3 individuals only (Salmo trutta). Two of these specimens were young fish (parr), and the gonads were not collected from these. The results from the tissues screened provides no clear pattern that can be used to support or reject any hypothesis about tissue/cell tropism in carriers, nor can the results be used to test any hypothesis about interspecies transmission of the ISAV. Cycle threshold (Ct) values from 38 and up are close to the detection limit for this real-time PCR and are not always reproducible. This explains why the second PCR on the kidney samples from Brekke and Nordgulen was negative. Further studies on tissue distribution of ISAV in carriers are needed.
The present study has shown that trout and salmon in Norwegian rivers are carrying ISAV and that these species could be the natural reservoirs for this virus. The importance of this natural reservoir, with respect to ISA in farmed salmon, has not been determined, nor can any conclusions be made about the influence of ISAV-infected farmed salmon on wild populations and their carrier status. These important questions for the management of ISA will require comparative studies of natural and man-made reservoirs over a longer timescale. Such studies will also rely upon the development of a typing system for the ISAV with respect to geographical origin and virulence.

\section{LITERATURE CITED}

Biering E, Falk K, Hoel E, Thevarajan J, Joerink M, Nylund A, Endresen C, Krossøy B (2002) Segment 8 encodes a structural protein of infectious salmon anaemia virus (ISAV); the co-linear transcript from Segment 7 probably encodes a non-structural or minor structural protein. Dis Aquat Org 49:117-122

Bouchard DA, Brockway K, Giray C, Keleher W, Merrill PL (2001) First report of infectious salmon anemia (ISA) in the United States. Bull Eur Assoc Fish Pathol 21(2):86-88

Cook-Versloot M, Griffiths S, Cusack R, McGeachy S, Ritchie $R$ (2004) Identification and characterisation of infectious salmon anaemia virus (ISAV) haemagglutinin gene highly polymorphic region (HPR) Type 0 in North America. Bull Eur Assoc Fish Pathol 24(4):203-208

Cunningham CO, Gregory A, Black J, Simpson I, Raynard RS (2002) A novel variant of the infectious salmon anaemia virus (ISAV) haemagglutinin gene suggests mechanisms for virus diversity. Bull Eur Assoc Fish Pathol 22(6): 366-374

Devold M, Krossøy B, Aspehaug V, Nylund A (2000) Use of RT-PCR for diagnosis of infectious salmon anaemia virus (ISAV) in carrier sea trout Salmo trutta after experimental infection. Dis Aquat Org 40:9-18

Devold M, Falk K, Dale OB, Krossøy B, Biering E, Aspehaug V, Nilsen F, Nylund A (2001) Strain variation, based on the hemagglutinin gene, in Norwegian ISA virus isolates collected from 1987 to 2001: indications of recombination. Dis Aquat Org 47:119-128

Griffiths S, Melville K (2000) Non-lethal detection of ISAV in Atlantic salmon by RT-PCR using serum and mucus samples. Bull Eur Assoc Fish Pathol 20(3):157-162

Hovland T, Nylund A, Watanabe K, Endresen C (1994) Observation of infectious salmon anaemia virus (ISAV) in Atlantic salmon (Salmo salar L.). J Fish Dis 17:291-296

Hungnes O, Jonassen TØ, Jonassen CM, Grinde B (2000) Molecular epidemiology of viral infections: how sequence information helps us understand the evolution and dissemination of viruses. APMIS 108:81-97

Jones SRM, Groman DB (2001) Cohabitation transmission of infectious salmon anemia virus among freshwater-reared Atlantic salmon. J Aquat Anim Health 13:340-346

Jones SRM, MacKinnon AM, Salonius K (1999) Vaccination of freshwater-reared Atlantic salmon reduces mortality associated with infectious salmon anaemia virus. Bull Eur Assoc Fish Pathol 19(3):98-101

Kibenge FSB, Garate ON, Johnson G, Arriagada R, Kibenge MJT, Wadowska D (2001) Isolation and identification of 
infectious salmon anaemia virus (ISAV) from Coho salmon in Chile. Dis Aquat Org 45:9-18

Knipe DM, Howley PM (2001) Fields virology. Lippincott Williams \& Wilkins, Philadelphia, PA

Krossøy B (2002) A genetic characterisation of infectious salmon anaemia virus (ISAV). D Sci thesis (DSc), University of Bergen, Bergen

Krossøy B, Hordvik I, Nilsen F, Nylund A, Endresen C (1999) The putative polymerase sequence of infectious salmon anemia virus suggests a new genus within the Orthomyxoviridae. J Virol 73:2136-2142

Krossøy B, Nilsen F, Falk K, Endresen C, Nylund A (2001) Phylogenetic analysis of infectious salmon anaemia virus isolates from Norway, Canada and Scotland. Dis Aquat Org 44:1-6

Kvenseth AM (1998) Wrasse-do they transfer diseases to salmon? Caligus 5:2-4

Løvdal T, Enger $\varnothing$ (2002) Detection of infectious salmon anemia virus in sea water by nested RT-PCR. Dis Aquat Org 49:123-128

Mackay IM, Arden KE, Nitsche A (2002) Real-time PCR in virology. Nucleic Acids Res 30(6):1292-1305

McClure CA, Hammell KL, Dohoo IR, Nerette P, Hawkins LJ (2004) Assessment of infectious salmon anaemia virus prevalence for different groups of farmed Atlantic salmon, Salmo salar L., in New Brunswick. J Fish Dis 27: 375-383

Melville KJ, Griffiths SG (1999) Absence of vertical transmission of infectious salmon anemia virus (ISAV) from individually infected Atlantic salmon Salmo salar. Dis Aquat Org 38:231-234

Mikalsen AB, Teig A, Helleman AL, Mjaaland S, Rimstad E (2001) Detection of infectious salmon anaemia virus (ISAV) by RT-PCR after cohabitation exposure in Atlantic salmon Salmo salar. Dis Aquat Org 47:175-181

Mjaaland S, Rimstad E, Falk K, Dannevig BH (1997) Genomic characterization of the virus causing infectious salmon anaemia in Atlantic salmon (Salmo salar L.): an orthomyxo-like virus in a teleost. J Virol 71(10): 7681-7686

Mjaaland S, Hungnes O, Teig A, Dannevig BH, Thorud K, Rimstad E (2002) Polymorphism in the infectious salmon anemia virus hemagglutinin gene: importance and possible implications for evolution and ecology of infectious salmon anemia disease. Virology 304:379-391

Mullins JE, Groman D, Wadowska D (1998) Infectious salmon anaemia in salt water Atlantic salmon (Salmo salar L.) in New Brunswick, Canada. Bull Eur Assoc Fish Pathol 18(4): $110-114$

Nylund A, Jakobsen P (1995) Sea trout as a carrier of infectious salmon anaemia virus. J Fish Biol 47:174-176

Nylund A, Wallace C, Hovland T (1993) The possible role of Lepeophtheirus salmonis in the transmission of infectious salmon anaemia. In: Boxshall G (ed) Pathogens of wild and farmed fish: sea lice. Ellis Horwood, Chichester, p 367-373

Nylund A, Alexandersen S, Løvik P, Jakobsen P (1994a) The response of brown trout (Salmo trutta L.) to repeated challenge with infectious salmon anaemia (ISA). Bull Eur Assoc Fish Pathol 14(5):167-170

Nylund A, Hovland T, Hodneland K, Nilsen F, Løvik P (1994b) Mechanisms for transmission of infectious salmon anaemia (ISA). Dis Aquat Org 19:95-100

Nylund A, Alexandersen S, Jakobsen P, Rolland JB (1995a) Infectious salmon anaemia (ISA) in brown trout. J Aquat Anim Health 7:236-240

Nylund A, Kvenseth AM, Krossøy B (1995b) Suceptibility of wild salmon (Salmo salar L.) to infectious salmon anaemia (ISA). Bull Eur Assoc Fish Pathol 15(5):152-156

Nylund A, Kvenseth AM, Krossøy B, Hodneland K (1997) Rainbow trout (Onchorhynchus mykiss, Walbaum, 1792): a carrier of infectious salmon anaemia (ISAV). J Fish Dis 20:275-279

Nylund A, Krossøy B, Devold M, Aspehaug V, Steine NO, Hovland T (1999). Outbreak of ISA during first feeding of salmon fry (Salmo salar). Bull Eur Assoc Fish Pathol 19(2): 70-74

Nylund A, Devold M, Mullins J, Plarre H (2002) Herring (Clupea harengus): a host for infectious salmon anemia virus (ISAV). Bull Eur Assoc Fish Pathol 22(5):311-318

Nylund A, Devold M, Plarre H, Isdal E, Aarseth M (2003) Emergence and maintenance of infectious salmon anemia virus (ISAV) in Europe: a new hypothesis. Dis Aquat Org 56:11-24

Page RDM (1996) TREEVIEW: an application to display phylogenetic trees on personal computers. Comp Appl Biosci 12:357-358

Raynard RS, Murray AG, Gregory A (2001a) Infectious salmon anaemia virus in wild fish from Scotland. Dis Aquat Org 46:93-100

Raynard RS, Snow M, Bruno DW (2001b) Experimental infection models and susceptibility of Atlantic salmon Salmo salar to a Scottish isolate of infectious salmon anaemia virus. Dis Aquat Org 47:169-174

Ritchie RJ, Cook M, Melville K, Simard N, Cusack R, Griffiths $\mathrm{S}$ (2001) Identification of infectious salmon anaemia virus in Atlantic salmon from Nova Scotia (Canada): evidence for functional strain differences. Dis Aquat Org 44: $171-178$

Rodger HD, Turnbull T, Muir F, Millar S, Richards RH (1998) Infectious salmon anaemia (ISA) in the United Kingdom. Bull Eur Assoc Fish Pathol 18(4):115-116

Rolland JB, Nylund A (1998a) Sea running trout: carrier and transmitter of the infectious salmon anemia virus (ISAV). Bull Eur Assoc Fish Pathol 18(2):50-55

Rolland JB, Nylund A (1998b) Infectiousness of organic materials orienting in ISA-infected fish and transmission of the disease via salmon lice (Lepeophtheirus salmonis). Bull Eur Assoc Fish Pathol 18(5):173-180

Rolland JB, Winton JR (2003) Relative resistance of Pacific salmon to infectious salmon anaemia virus. J Fish Dis 26: 511-520

Rowley HM, Campell SJ, Curran WL, Turnbull T, Bryson DG (1999) Isolation of infectious salmon anaemia virus (ISAV) from Scottish farmed Atlantic salmon, Salmo salar L. J Fish Dis 22:483 -487

Snow M, Raynard RS, Bruno DW (2001a) Comparative susceptibility of Artic char (Salvelinus alpinus), rainbow trout (Oncorhynchus mykiss) and brown trout (Salmo trutta) to the Scottish isolate of infectious salmon anaemia virus. Aquaculture 196:47-54

Snow M, Raynard RS, Inglis J, Bruno DW (2001b) Investigation into the potential for seawater rainbow trout (Oncorhynchus mykiss) to act as vectors of infectious salmon anaemia virus (ISAV). Bull Eur Assoc Fish Pathol 21 (6):252-262

Snow M, Raynard R, Bruno DW, van Nieuwstadt AP, Olesen NJ, Løvold T, Wallace C (2002) Investigation into the susceptibility of saithe Pollachius virens to infectious salmon anaemia virus (ISAV) and their potential role as a vector for viral transmission. Dis Aquat Org 50:13-18

Snow M, Raynard RS, Murray AG, Bruno DW and 5 others (2003) An evaluation of current diagnostic tests for the detection of infectious salmon anaemia virus (ISAV) fol- 
lowing experimental water-borne infection of Atlantic salmon, Salmo salar L. J Fish Dis 26:135-145

Swofford DL (1998) Phylogenetic analysis using parsimony and other methods, Version 4.0. Sinauer Associates, Sunderland, MA

Thorud KE (1991) Infectious salmon anaemia: transmission trials - haematological, clinical chemical and morphological investigations. PhD thesis, National Veterinary Institute, Oslo

Thorud K, Djupvik HO (1988) Infectious anaemia in Atlantic

Editorial responsibility: Jo-Ann Leong,

Kaneohe, Hawaii, USA salmon (Salmo salar L.). Bull Eur Assoc Fish Pathol 8(5): $109-111$

Thorud K, Torgersen Y (1994) Regnbueørret og sjøørretkan være passive smittebærere av ILA. Norsk Fiskeoppdrett 11A:54-55

Totland GK, Hjeltnes BK, Flood PR (1996) Transmission of infectious salmon anaemia (ISA) through natural secretions and excretions from infected smolts of Atlantic salmon Salmo salar during their presymptomatic phase. Dis Aquat Org 26:25-31

Submitted: July 9, 2004; Accepted: April 14, 2005

Proofs received from author(s): July 11, 2005 